Lima, V. (2020). The Institutionalisation of Social Movements: Co-Optation and Democratic Policy-Making. Political Studies Review

https://doi.org/10.1177/1478929920913805

\title{
The Institutionalisation of Social Movements: Co-Optation and Democratic Policy-Making
}

\author{
Valesca Lima, Maynooth University
}

\begin{abstract}
Over the past 30 years, urban policy in Brazil has undergone a major transformation, both in terms of regulatory frameworks and the involvement of citizens in the process of policymaking. As an intense process of institutional innovation and mobilisation for decent public services took place, academics started to consider the impact of institutionalisation on the autonomy of social movements. Using empirical evidence from a city in the northeast of Brazil, this article addresses the wider literature on citizen participation and social movements to examine specifically the problem with co-optation. I examine the risks linked to co-optation, risks that can undermine the credibility of social movements as agents of change, and explore the tensions that go beyond the 'co-optation versus autonomy' divide, an issue frequently found in the practices of social movements, in their dealings with those in power. In particular, this article explores the learning processes and contentious relationships between mainly institutionally oriented urban movements and local government. This study found that the learning of deliberative skills not only led to changes in the objectives and repertoires of housing movements, but also to the inclusion of new components in their objectives that provide room for creative agency and which, in some cases, might allow them to maintain their autonomy from the state.
\end{abstract}

Keywords: participatory democracy, housing, institutionalisation, policy councils

\section{Introduction}

Brazilian cities have a rich history of social movements engaging with public policymaking. For this reason, the relationship between these movements and policy-making has become one of the central themes in Brazilian studies on social movements (Abers et al., 2014). The centrality of this theme to the studies of autonomy and democratic innovation is evidenced in the numerous experiences of participatory democracy that involve citizens in the process of policy-making. 
Those experiences have implications for government performance and the collective action of social movements. Generally, the study of the integration of social movement demands has developed into studies about how institutionalisation impacts Social Movement Organisations (SMOs) and the consequences for the movements' ability to influence the government decisionmaking process (Lavalle et al., 2019).

The construction of Brazil's 'architecture of participation' saw social movements take on a major role in pushing for new citizenship rights and new policies for minority groups (Abers and Bülow, 2011; Dagnino and Teixeira, 2014; Tatagiba, 2011). After a phase where studies focused on what was perceived as the inherent bureaucratisation of institutionalised social movements (Albuquerque, 2019), more recent work has concentrated on the conditions that limit the influence and participation of social movements in democratic institutions (Bronstein et al., 2017; Lavalle et al., 2016) and on relations with the state through institutionalised channels, re-focusing attention on the effects of these interactions on social movements and their (self-declared) autonomy (Oliveira and Dowbor, 2018).

Democratic innovations have the potential to make the participatory process more accessible. The question of how SMOs affect public policy when included in decisionmaking or how they are changed by their inclusion is one that scholars have puzzled over for a long time (Abers and Bülow, 2011; Albuquerque, 2019; Dinerstein et al., 2013; Fominaya, 2015). The risk of co-optation is ever-present in cooperative practices involving political elites, one that might absorb those groups' agency for social change - an issue frequently found in the practices of social movements in terms of how they relate with those holding power (Gamson, 1990; Selznick, 1949). A primary concern in social movement literature is how to conceptualise and explain co-optation (Trumpy, 2008). Intriguingly, the issue of 'non-co-optation' has received much less attention (Holdo, 2019; Murphree et al., 1996; Nogueira, 2018) in scholarly work on participatory institutions where cooptation has resulted from the institutionalisation of social movements (Druck, 2006; Gohn, 2008; Lavalle et al., 2019; Meyer and Tarrow, 1998). Therefore, it remains a stimulating area for research, and additional studies on the institutionalisation of social movements and autonomy are needed.

On this issue, this article explores the tensions that go beyond the 'co-optation versus autonomy' divide by elaborating and making clearer which practices can be viewed as expressing autonomy and/or its opposing counterpart, co-optation. Much of the literature on participatory democracy in Brazil has been dominated by cases of participatory budgeting. This study examines a management policy council from the critical perspective of co-optation. More specifically, this article investigates under what conditions movements confront the state and when they cooperate with institutions. I argue that this integration has not only led to changes in the interaction between society and state, especially in terms of the scope of housing demands and repertoires, but it has also provided some room 
for creative agency when it comes to the participation of SMOs through learning experiences. To explore the learning processes that underline citizen participation, I use empirical data to examine the changes social movements go through at the sub-national level as a consequence of their integration in participatory institutions, in terms of how they change political repertoires, discourses and organisations in order to confront and/or cooperate with the state. The findings should make a refreshing contribution to the understanding of the conditions in which social movements confront or cooperate with institutions. Discussions on the learning of new skills can be enriched theoretically and empirically by an examination of social movement's capacity for creativity and agency, instead of their expected demobilisation or deradicalisation. These findings contribute with new insights to the literature on co-optation versus autonomy in the social movement and democratic innovation literature while, at the same time, they provide a critical view of the inclusion of social movements in participatory institutions.

The article is organised as follows: in the section 'Social Movements, Deliberative Learning and Co-Optation', I give an overview of the literature on social movements, institutional participation and co-optation. In the section 'Research Design and Methods', I present the research methodology. I then move to analyse SMO perspectives on changing their actions and attitudes towards democratic institutions in the section 'Integration or Co-Optation: The Case Study'. In the section 'The Influence of the Learning Process on the Protest Agenda of SMOs', I consider evidence of change in SMOs participating on the housing council, and in the section 'Conclusion', I discuss the specific impact of institutionalisation on the protest agendas of SMOs and reflect on the study's implications for traditional debates in the social movement literature on cooptation versus autonomy.

\section{Social Movements, Deliberative Learning and Co-Optation}

Social movements being viewed as political protests by outsiders, or as noninstitutionalised participation in political spaces, is a predominant view in both political opportunities and new social movement theory (Gamson, 1990; Jenkins and Klandermans, 1995; Tarrow, 2012). These interpretations constrain how the interactions of social movements with institutional politics are understood, as they have two main implications: first, these interpretations hinder the recognition of the mutually constitutive interactions between the movement and the political

system and the circumstantial combination between 'outsider' and institutionalised 'insider' action; and second, they interpret the engagement in political institutions as resulting from a process of institutionalisation of the movement which affects, exclusively and homogeneously, the organisational structure of collective action (Carlos, 2015). 
This homogenising view of patterns of institutionalisation assumes that activists and authorities adhere to a predictable model of collective action, where institutionalised social actors with access to the political system are co-opted, their demands are loosened and their autonomy vanished (Katzenstein, 1998). While it can be the case that the inclusion of social movements in institutional spaces encompasses an attempt to normalise and demobilise practices of collective autonomy (Dinerstein et al., 2013), it is, in fact, a complex relationship that changes the movements' organisational structure, such as routines, bureaucratisation and co-optation (Kriesi, 1996). This approach suggests that their integration into state structures changes their repertoire of confrontation (Tarrow and McAdam, 2001). Recent scholarship has shown that institutionalised social movements cannot be reduced to just their confrontations with the state for three reasons: (1) SMOs engage in a variety of activities that are not necessarily in conflict with the state, because movements can also collaborate in the elaboration and implementation of public policies; (2) social movements combine multiple forms of relationships with the state, which involves hybrid and creative models capable of promoting articulation between institutionalised and noninstitutionalised action and (3) the use of institutionalised channels in the repertoire of action and the formalisation of organisations does not necessarily lead to the demobilisation/co-optation of the movement (Lavalle et al., 2019: 39).

Autonomy is a major area of interest within the field of social movements and participatory democracy. As noted by Holdo's (2016a, 2016b, 2019) previous works, autonomy in the participatory process is closely connected to the learning of deliberative skills, as the author found that participants maintain their autonomy by developing new skills and a new kind of platform for themselves. Autonomy requires from engaged citizens mutual respect as part of the deliberation process, in order to make sure the conditions for participation are exercised and equal to all. Therefore, an essential part of democratic education is to learn how to deliberate well enough to be able to hold representatives accountable. However, it only happens when citizens learn how to use public reason and learn how to navigate the policy-making process, because models of collective action are not homogeneous. A variance in the outcomes of participation and learning happens for two reasons: first, because organisational patterns can vary according to the type of movement (Kriese et al., 1995) and second, they can vary according to political-institutional contexts (Canel, 1997; Rucht, 1995).

While much of the literature emphasises that institutionalised SMOs are destined for co-optation and disempowerment, more optimistic accounts also exist (O'Hare, 2018). Co-optation is understood here as the process of absorbing new elements into the leadership structure of the organisation as a means of survival, where movement members are given some voice, in order to control their potential for disruption and to limit their demands, in the classic view of Selznick (1949). This view of co-optation has been adopted in other works on co- 
optation (i.e. Coy and Hedeen, 2005; Schwartz, 2010). Despite operating in restrictive contexts often marked by clientelism and corruption (Selee and Peruzzotti, 2009), participants can maintain a critical distance from government (Coaffee and Healey, 2003), pursue their own agenda (de Jong and Kimm, 2017) and criticise government. To maintain autonomy does not fundamentally challenge existing power relations, but it means a certain degree of resistance to government powers predisposed to co-opt groups with divergent ideas. This is the point where the tension between autonomy and co-optation arises. This framework of expected co-optation does not, however, prevent SMOs from criticising government decisions or from not engaging with government when needed. For SMOs that choose to act through institutions to meet their demands, a 'conflictual cooperation' is possible (Giugni and Passy, 1998; Nogueira, 2018). Avritzer (2009) and Selee and Peruzzotti (2009) found that participants must be willing to employ both contentious and cooperative political strategies, since to employ only cooperation is more likely to lead to co-optation and to employ only contention is to risk polarisation and the dissolution of participatory practices entirely (Nylen, 2011).

There are numerous instances of the use of co-optation as a 'neutralisation' or 'taming' of more radical social movements (Coy and Hedeen, 2005; Rossi, 2017; Trumpy, 2008; Wolff, 2007). In Ecuador, for example, the indigenous movement gained a political voice through institutional participation, even if it has not led to a relevant 'democratic deepening' to date, while the Piqueteros in Argentina fell into the intricate politics of the Peronist party, leading to the fragmentation of the movement (Wolff, 2007). However, there are well-established explanations for why co-optation is not always the end result of institutionalisation. The first is that social movements are, in some cases, able to use a form of 'countervailing power' to resist co-optation efforts (Wampler, 2007). Countervailing power is a mechanism that can reduce, and perhaps even neutralise, the power-advantages of ordinarily powerful actors (Fung and Wright, 2003). The capacity to resist cooptation depends, in part, on the resources, on the organisational skills of the challengers and on the shape of the political institutions in which that power operates. The second reason is that SMOs are more successful in maintaining their autonomy when they enjoy significant levels of self-organisation prior to participation (Baiocchi, 2001). Otherwise, participation may undermine the independence of SMOs. The third reason is that the learning of deliberative skills helps participants to maintain their autonomy, as they develop new skills that allow them to formulate their concerns in the terms dictated by institutionalised participation while standing by their interests and goals and keeping their sense of autonomy (Holdo, 2016a). In the context of participation, the nature of deliberative skills involves the development of skills and competencies integrated with actual experiences of public policy decision-making, together with skills in debating and mobilising resources for collective goals (Fung and Wright, 2003). 
One of the ways to understand the central role of the deliberation-specific and organisational skills necessary for participants to maintain their autonomy is through studies that contribute empirically to the discussion on the limitations of conventional views of co-optation versus autonomy. Much research has examined the relationship between institutionalised movements and the state (Dagnino and Tatagiba, 2010; Rich, 2019; Tatagiba, 2011) and how far this relationship dismisses practices of collective autonomy (Bronstein et al., 2017; Dinerstein et al., 2013; Kriesi, 1996). However, research on social movement autonomy has been limited and little has been done concerning the relevant kind of skills needed to bring the voice of marginalised groups into policy-making areas. The importance of outlining alternatives to the notion of co-optation from the perspective of autonomy and learning should not be overlooked. This article is a response to this need, and it argues that new skills gained from institutional learning, such as new ways to solve conflict, negotiation and participation routines, can provide wellorganised SMOs with additional competencies to maintain their autonomy and affect the policy process. Hence, the starting point for this study is the tension between co-optation and autonomy, an issue frequently found in the practices of social movements in their relations with those holding power. From the perspective of examining the diversified interaction repertoires between social movements and the state, this study analyses the conditions in which co-optation occurs (or does not occur) and how these skills have been used, combined and transformed by social movements wishing to keep their autonomy.

\section{Research Design and Methods}

This study is based on evidence from 29 semi-structured interviews, performed with current and former members of a municipal housing council, in the city Maracanaú, a mediumsize municipality in the northeast of Brazil, in the state of Ceará. Although a large number of case studies on participatory institutions have been published to date in Brazil, most are performed in large cities, and many commit the error of presuming that what happens in São Paulo and Rio de Janeiro is 'representative' of Brazil (Garmany, 2011). There are significant differences between social movement repertoires of action in smaller cities like Maracanaú and those in larger cities. While urban movements in Rio de Janeiro and São Paulo have more often focused on the defence of their right to occupy and access space in the city, the demands of groups in cities such as Caucaia and Maracanaú (metropolitan areas of Fortaleza, in the state of Ceará) tend to focus upon better housing, infrastructure and improved public services (Coelho and Costa, 2017; de Oliveira Santos, 2013; Lima, 2011, 2018). The growth and expansion of urban movements, especially the ones related to access to housing have progressed differently in Ceará - and in the northeast region in general - where shantytown communities confront a unique blend of challenges and neighbourhood issues, such as drug trafficking, environmental degradation and relentless poverty (de 
Almeida, 2005; Freitas, 2014; Garmany, 2014; Scheper-Hughes, 1992). In studying contemporary urban movements, it is important to understand how their actions to transform the built environment affect the ongoing activities of movements seeking to influence urban policy, an area in which some technical elements and top-down urban planning make it particularly relevant in understanding SMO attempts to build democratic urban spaces rooted in local cultures (Hamel, 2014).

The effects of institutionalisation on SMOs needs to be constantly examined and case studies are useful in capturing these changes at a deeper level. During fieldwork carried out between 2014 and 2015, I interviewed social movement representatives, civil servants and housing activists. The latter grouping is chiefly composed of members of neighbourhood associations demanding better housing and infrastructure in their areas. The interview technique was chosen as it provides rich data on the council members' views and perspectives. The indepth interviews followed an interview script, in which council members were asked about their experience on the housing council, their expectations and perspectives, and about challenges to their participation in policy-making. Asking participants about the problems and challenges on the council generated rounded, detailed illustrations of their political activities in the housing council. Interviews alone are not a definitive tool for capturing political practices that are actually driven by the prospect of co-optation, because participants might try to appear more autonomous than they really are (Holdo, 2016a; Wampler, 2007). Nevertheless, interviews provide important material about the perceived conditions for political action in an institutional setting. Where a problem of selection bias exists, this study is unable to develop a fuller picture of the mechanisms of non-co-optation through a case study. Thus, based on this particular material, the nature of the empirical claims in this study focused on the degree to which participants criticise government (Abers, 2000; Wampler, 2007) and their perceived capacity to influence policy decisions (Wampler, 2007).

The interviews took place in the participant's homes or other places at their convenience (home, workplace, café and library). This research obtained ethical approval from my university ethics' committee and all interviews were recorded with consent. Other supporting materials were collected, such as council reports, newspapers articles and policy documents to be used in data triangulation in order to corroborate the information given by the respondents. Data obtained from the interviews and other documents were analysed using qualitative content analysis (Boyatzis, 1998; Saldaña, 2009). The interview data were grouped around main themes so as to perform a triangulation of the evidence and validate the results of the analysis. The interview script was used as a basis for the analysis and it allowed for the identification of key transitions and critical moments in the context of participation in the municipal housing council. All of the interviews were transcribed and analysed with the assistance of NVivo software. The interpretation of the research findings is presented in relation to the narratives 
that express autonomy and/or its opposing counterpart, which is the framework of reference of this study.

\section{Integration or Co-Optation: The Case Study}

The systematic institutionalisation of social movements during the Workers' Party administrations in Brazil (2003-2016) had a number of distinct characteristics and produced significant impacts. First, the institutionalisation of a large number of SMOs connected to a variety of social groups (indigenous communities, women, Black people, elderly, LGBT (lesbian, gay, bisexual, and transgender)), both incorporated underrepresented groups into the state bureaucracy and brought new voices to participatory institutions (Dagnino and Teixeira, 2014). Second, the integration of social movements into the state came with the implicit consent of the country's ruling elites (Nogueira, 2018). Third, the Workers' Party administration created spaces within government (i.e. policy councils) and outside government (i.e. national conferences) (Avritzer, 2010). Fourth, in relation to urban policy, the creation of the Ministry of Cities in 2003 represented an institutionalisation of historic demands from urban social movements. It brought together housing, sanitation and urban transportation policies, which had been spread across 14 different ministries and secretariats since 1985. This new urban reform agenda gave way to unprecedented advances in urban policies in terms of broadening social participation and articulation between sectoral urban policies (Buonfiglio, 2017) but it was severely constrained by the government's economic team (Rolnik, 2019). Other authors have criticised the lack of consistent debate about the meaning of participation in this process (Maricato, 2014; Rodrigues, 2012).

The housing movements analysed in this article emerged in the context of a postdemocratisation transition during the 1990s. The majority of these movements have more than 10-20 years of existence, a long story of housing action as NGOs and grassroots groups with a tendency towards moderation in critical positions taken relative to existing political institutions. Only two neighbourhood groups would be considered more radical and would organise building occupations. While some are exclusively dedicated to the housing issue, others are also engaged with organising and mobilising neighbourhood movements, and their agenda includes demands for social and urban improvements in public services, such as access to healthcare and good quality education. Influenced by the powerful housing movements at the national level, housing movement members of the municipal housing council in Maracanaú focus their agenda on social housing provision, tenants' rights and urban infrastructure development for slum areas (Lima, 2018). The political orientation of the local government has been largely right-wing since the creation of the municipality in 1986. It was governed by a coalition of right and centre parties during the fieldwork period. Previous administrations created several participatory 
institutions to oversee policies at the local level, after the enactment of the 'architecture of participation', implemented by the leftist Workers' Party, starting in 2003, at the federal level (Dagnino and Teixeira, 2014). Policy council participants are elected for a 2-year mandate in a local policy conference organised for that purpose. To qualify for elections, housing movement representatives have to be formally registered with the municipal revenue and present proof of activities relating to the policy in question (in this case, activities relating to housing).

An expected outcome of SMO engagement in participatory institutions is that SMOs would coalesce to a predictable model of action: they would change their demands and struggle for autonomy (Meyer and Tarrow, 1998). As mentioned before, this type of approach does not put forward sufficient elements to give a full analysis of changes in the patterns of collective action that social movements carry out when dealing with participatory institutions. Instead of a highly formal model of participation, participatory institutions can combine mechanisms of participation with the process of elaborating and implementing public policies, creating a variety of possible arrangements, reflecting the characteristics of such a dynamic process.

Social movement studies have identified the streets as being the main locus of actions and confrontations with the state, instead of dialogue and consensus. Nevertheless, as presented above, some research has focused on different paths of actions that involve cooperation with government institutions (Nogueira, 2018). During the interviews, council members considered their own participation in the council, in terms of their autonomy to make decisions. In this participatory space, autonomy is limited but council members identify it as a key condition for being a member of the council, as illustrated by this respondent:

I believe the council needs independent people. I cannot be in the council if I am connected to political groups. I am not naming names; I am just saying it should not happen. It should be an autonomous person, someone to enforce the rules. My role is to defend the community. If you are not this person, it is a problem (Participant 12).

Once social movement activists become part of state institutions, their actions go beyond the groups that they represent. In participatory institutions, such as the housing council under analysis, these movements are inserted into a hierarchy that limits their autonomy and submits their actions to the veto power of actors with a different logic, one that involves party politics and government coalitions. The result may be that, upon entering the institutional space, activists from social movements end up defending more moderate positions or even positions that are contrary to the movement's mission (Abers and Bülow, 2011). Interviewees were asked about the possibility of losing autonomy, especially if they could identify when and how autonomy was under risk. The majority of respondents replied to this question by comparing actions before and after joining the council, 
when they observed changes from 'active' to 'passive' political behaviour, as explained by this council member:

[. . .] maybe this person will not act according to their beliefs, but they will act in the way government wants her to act. [. . .] It could be anything, from not engaging in debates to not showing up to council meetings. Of course, we have to negotiate a lot, inside and outside the council, so not to take part in this process, it is odd ... What is this person doing there anyway? (Participant 28).

Council members may resort to more passive attitudes because they have incentives: they may be rewarded with key information on housing projects or even political support in future municipal elections. It works as a shortcut to their political goals. By aligning with the government, some SMO members can obtain benefits that otherwise would be much more difficult to obtain.

In this context, giving away some autonomy can become a tool of control whereby the traditional political elites successfully absorb elements of contestation to carry out reforms at a more fundamental level, maintaining the stability of the political order they want to preserve (Munck, 2013: 49). At the local level, the 'benefits' of being involved in institutional practices may be associated with an enhanced status, an opportunity to influence particular (but discrete) aspects of public policy decisions, such as an opportunity to secure a job, even if temporary or a 'place at the table' in order to have access to senior managers and professionals.

What some would identify as 'co-optation' or 'passiveness' is, in fact, an expected part of the process of participating in government institutions (Dinerstein et al., 2013), but this is much more complex. The SMO approach to the housing issue consists of a mix of cooperation and contestation, as also observed by Lavalle et al. (2019), Abers et al. (2014) and Holdo (2019). This 'softer approach' was interpreted as 'change of strategy' by SMO members of the housing council. Furthermore, they explained that this is a conscious decision based on what they have learned from their participation on the council. As this council member clarifies:

What we did, myself in particular, I decided to learn more about social (housing) programmes. I realized that I was doing some things in the wrong way, because I had no knowledge. Now I feel I'm defending my community's rights (Participant 20).

SMO members of the housing council explained that they came to the council with idealised expectations at the beginning, but that they soon learned the limitations of implementing the model of social housing they believed in. This learning process suggests important changes for SMOs because acquiring skills on how to negotiate and articulate their agendas helps to disseminate democratic practices that could, in turn, change practices that were/are shaped by the 
historical pattern of the clientelist, paternalist and authoritarian political culture characteristic of the region (Bohn, 2011; Van Dyck and Montero, 2015).

The state is often seen as resistant to encouraging social movement groups to maintain their autonomy (Lima, 2019) and, it is often assumed, to co-opt them. While some council members spoke of learning and trying to overcome limitations through dedication and a commitment to acquiring new skills, others reflected on the role that council members play in the council as a way to securing a minimal level of legitimacy for government decisions and how not all council members are actually independent from government. As suggested by this interviewee, some council members do not exercise their role as representatives and instead side with the government, which prevents them from pushing their community's agenda:

I think there is no legitimacy for social participation in this space, I think they use it to legitimize government actions, why? Because we do not see grassroots social movements, it's all really rigid. They are not there just to say yes or no. They are there to represent, to speak for the community they represent. If they are not ready to do that, I do not know what they are doing there (Participant 17).

When asked about changes in the way they approach the state with housing demands, SMO council members stated that many limitations are in place and that they have to work around them. This SMO member quoted below explained how it was a challenge for them, but once they learned about public policy processes and social housing legislation, they became more knowledgeable on public policy-making in general:

It is understandable that people want to get things done quickly, but that is not how it works [. . .] There are steps, phases, bids, whatever, lots of bureaucracy. We have to wait but stay strong (Participant 4).

As this participant puts it, once they were fully conscious of the opportunities and limitations involved in pushing his association's agenda forward on the council, it was necessary for them to review their strategies in the association. Waiting for the results from the housing council seems to be one of the most difficult parts of this process for SMOs. The interview analysis suggested that 'to wait', or being patient and perseverant, seems to be one of the main characteristics of those representatives. Considering this experience from the point of view of being an expression of autonomy or symptoms of co-optation, it seems to be none of those. Bearing in mind that SMOs are inserted into a hierarchy that limits their autonomy and submits their actions to the veto of state bureaucracy, the result may be that, upon entering the state apparatus, activists in social movements take more moderate positions, as seen in Giugni and Passy (1998) and Abers and Bülow (2011) - one of the consequences of collaborating with the state is a moderation of one's objectives. 
SMOs inside the housing council learn and understand the participatory process and then adapt to it. While these facts are largely recognised by the literature, an original insight in this case is that this adaptation can be observed in the way SMOs make demands on the council - resolutions instead of street protests, negotiation instead of building occupation and cooperation instead of only contestation with the state. More specifically, the council has approved resolutions that monitor the inclusion of families on the housing list, as they accept that the criteria for delivering housing are fair. Other examples are that the council did not support a building occupation carried out by housing activists who were not members of the council, and that they help government officials to organise events and courses relating to housing policy. ${ }^{1}$

Changes, however, are not homogeneous. SMOs do not always pursue an innovative, systematic and functional agenda to adapt to their new situation as participants of public policy-making. As pointed out by Lavalle and Bueno (2011) and Carlos (2015), dissimilar patterns of participation in participatory institutions are made up of different repertoires, strategies and skills that SMO participants implement and develop in order to increase their influence on the political agenda. These different competencies and strategies that SMOs' representatives develop and learn by being integrated in participatory institutions signal the (re)construction of relations with the state and might also explain the success, strengthening strategies and even failure of the housing agenda of the SMOs.

\section{The Influence of the Learning Process on the Protest Agenda of SMOs}

Social movement representatives who are members of the housing council display an understanding of the limitations and possibilities for their communities when it comes to access to social housing. They show awareness of what they can obtain for their communities, despite having difficulties in accessing information and open channels of communication with public officials. This is related to a learning process that, in this context, explains why social movements may change their strategies and tactics once they are integrated into spaces of participatory decision-making and not necessarily end up coopted or demobilised. I will now move to examine the influence of this learning process and the new skills SMOs pick up as members of the housing council.

The learning process is challenging to track in terms of relevance and impact. Consensus and power sharing are more difficult to achieve because of the complexity of the policy-making process, resistance by government officials and council members' internal disputes. To influence government to attend to their demands, SMOs in the council have to adapt to their new situation. This former SMO representative on the housing council commented on what changed after their organisation joined the council: 
So, those entities, they learn that they need to adjust to the new political context. The political, cultural and economic context. Whether they want to or not, it is not easy to adjust and if they do not update ... they will be out. Unless they come just to be there watching ... But the council itself, it will ask for those things from you (Participant 8).

That data suggest that SMO demands on the housing council do not change completely, but that they are adapted; and real change takes place in the way they approach government to make claims. Institutionalisation brings dilemmas and challenges for SMOs, most notably through pressure to contain their criticisms or moderate their demands (Abers and Keck, 2009). The participants, on the whole, suggested that their demands are more specific, as they try to fit them into housing legislation. Unfortunately, for them, this adaptation to a new political situation indicates they have to 'aim lower' or demand less from government. Again, this is not exactly a sign of effective co-optation, but a potential sign of the scaling down of demands and strategies, in light of their new situation.

SMOs have to adapt to this restricted space when making demands on the housing councils. In other words, SMOs face clear limitations when joining structures of local government and, although spaces of negotiation have been opened, they react against the different interests that are at stake, while they reevaluate their chances of success. This can be seen when SMO council members start to demand less, as illustrated in this quote:

It does make sense, look: we need 1,500 housing units, right? Maybe more. If I say that in the [council] meeting, people will roll their eyes at me, they know this is not going to happen. So, we ask for 100, let's say. That makes more sense. [. . .] Because funding for 100 house units is easier to obtain (Participant 11).

This view was echoed by another informant who mentioned organisational learning from both of their previous struggles, as council participants adapt to the new form of interaction:

We understand now how it is; it has a whole series of criteria that need to be taken seriously: rules for income levels, having no other home, the waiting list, etc. etc. That is why, as I said before, it is nice to be inside because we feel more informed and connected to what is happening (Participant 22).

The council member understood that when members present ambitious demands, their community might not see concrete results. The learning process is visible here when they lower their expectations, as if it was required for council members to stay grounded and reduce or reframe their demands. Also, contrary to the perspective that says that the movement's participation in implementing policies through agreements with the state necessarily means it was co-opted (Albuquerque, 2019), the experience of participating on the housing council gives its participants knowledge and expertise that enable council members to exert 
their critical and propositional capacity. By attending meetings, and studying and debating, they are then qualified to exercise social control and formulate policy. As one of the respondents noted:

[...] that is why it is important for the council members to attend the meetings, because when we start this job we do not know about these policies. It is a learning process. I see people, mostly from civil society, studying, trying to learn about that social policy, that is an enriching process (Participant 7).

Dagnino and Tatagiba (2010) examined the institutionalisation of institutions and looked at the difficult learning process that participation involves. The need for policy and technical knowledge is a necessary condition for effective participation, a fact that is clearly recognised by social movements. It then becomes part of their repertoire of action, occupying a lot of the time and energy of their participants.

Research on the topics of clientelism and patronage has shown that community inclusion and investments in social welfare invest local communities with autonomy in order to make their own political choices (Bohn, 2011; Van Dyck and Montero, 2015). But if local policy councils are a space to promote transparency by giving 'the power to oversee' to local communities, they are also a space of dispute. The council did increase the number of voices that have access to the government agenda, but it is clear that those voices have difficulties being heard.

On the one hand, the inclusion of new voices changes the dynamic of the policy councils and increases the possibility that SMO demands will be included in the government agenda. On the other hand, despite more access to information, council members are limited in the demands they are able to make. Rather than the government adapting in order to work cooperatively with SMOs, it was SMOs themselves who had to change in order to remain as members on the housing council. As a result, SMOs engaged in the institutional space might, over time, prefer this type of action over more radical actions (street protest and building occupation, for example), which would impact their capacity to mobilise. But this is a generic possibility that requires more empirical investigation, as pointed out by Tatagiba (2011).

How cooperative interaction with the government takes place varies according to SMO demands. Movements with negotiable demands and proposals that are permeable to the government agenda tend to cooperate with the government, while movements advocating claims considered non-negotiable, and which constitute a risk to the government, are less likely to collaborate (Carlos, 2015). Movements with non-negotiable and hard-toreach demands are considered to be contentious and conflictive in view of the incompatibility of purposes and the interests of the state representatives.

Generally, deliberative democracy theory holds autonomy as an important requirement for the learning of democratic skills. As a result of participation, every actor engaged in the deliberative process has to give the autonomy of others important consideration. Therefore, examining the process of learning 
deliberative skills involves not only exploring the conditions around deliberation on the housing council but also examining how council members have changed their views and their approach to housing policy through the councils. They changed, not necessarily through co-optation only, but by gaining skills that allowed them to understand how the policy process works. In examining the learning process from inside the council, this study has identified ways in which participation in policy-making can constrain people's autonomy and/or allow for the learning of new skills. For example, skills in public deliberation and public speaking help the social movement to form a strong relationship with the state, and this involves creative models for articulating their participation in institutions while holding the right to make claims on the state.

The research results have also shown that SMOs tend to reduce their expectations and scale down their goals. The possibility of co-optation is a constant risk for social movements and can indeed happen more often than not. However, this idea of co-optation being a certainty - as a direct result of being active in institutions - does not mean that SMOs cannot be critical of government policy and cannot reformulate their strategies for action. The simultaneous existence of participation models that involve working in institutions in order to meet demands can also help to convert the SMO agenda into policy actions and can protect from co-optation attempts. This possibility is at the core of the debate about social movement autonomy, both within participatory institutions and outside them. The idea of learning new skills presented in this article is important when understanding the learning journey of SMOs and the lessons they learn from participating in the monitoring, evaluation and implementation of public policy.

\section{Conclusion}

This article has examined the dynamic interactions between social movements and institutional integration and explored tensions in the areas of co-optation and the institutionalisation of social movements. In exploring which practices can express autonomy or co-optation, this study has identified the new skills that SMO representatives pick up from their institutional experience which can provide wellorganised SMOs with the potential to preserve their autonomy within spaces of policy-making. While co-optation is expected to occur routinely - and this study does not completely disregard that possibility - the particular dynamics and implications of non-co-optation are explained in this study. The analysis centres on evidence of learning and change.

One of the more significant findings to emerge from this study is that the ability of SMO groups to enter the institutional space without being co-opted requires that the processes of organisational transformation must have been conditioned both by their previous struggles and by the practical skills they learn along the way. These skills include learning about participatory routines, legislation, 
negotiation and new ways to solve conflict. The development of deliberative skills and competencies that can influence the policy process, together with organisation-level learning, can prevent SMOs from declining or being entirely co-opted. The concrete construction of acquired skills to negotiate and participate in an environment where power is skewered to one side - it is the government who leads the policy elaboration process - requires reflection and maturity from SMOs, in combination with opportunities to influence the policy process. In summary, this new repertoire of institutional participation includes less confrontation and more negotiation. Therefore, it is possible to argue that the adoption of collective action strategies from within the bureaucratic apparatus of the state does not necessarily lead to co-optation or demobilisation, as it can be combined with autonomy and institutional learning.

The results presented in this study have important implications for pushing conventional debates in the social movement literature on 'co-optation versus autonomy' to include the perspective of non-co-optation and when/how this might occur. In uncovering new processes and mechanisms by which SMOs have changed their strategies of collective action, the research findings suggest that transformations in how SMOs are organised are a consequence of their engagement, configurated by participants' willingness and capacity to combine cooperation and contestation to reach their goals. While collaborative interaction might have some positive effects on collective action, on the one hand, such as the creation of access points, conflict resolutions, learning and a new partnership between SMOs and the government; on the other hand, SMOs have the challenge of maintaining their political autonomy, because this collaboration can create disproportionate connections with government members, which could reduce their capacity to make demands and influence public policy.

My work contributes to the literature on the institutionalisation of social movements and makes an important contribution to our understanding of cooptation. Few recent studies have specifically focused on analysing the various impacts of institutional insertion on the movements. Largely used to support the theoretical and empirical claims in this study, they help break the dualist view that has simply put 'autonomy versus cooptation' in the social movement literature. Notwithstanding the limits imposed by case study research, this work offers valuable insights into the learning experience of SMOs in participatory institutions and how this learning can be used to retain autonomy. Moreover, to analyse and evaluate the results and consequences of the actions of movements being institutionalised is not an easy task. The answers provided here are not conclusive and the issues raised in this article would be a fruitful area for further work. For example, further studies could assess the long-term effects of institutionalisation on traditional SMOs. More information on how SMOs are integrated into the institutional space might ultimately favour a greater degree of accuracy on this matter. 


\section{Acknowledgements}

I would particularly like to thank my former supervisors Dr Melanie Hoewer and Professor David Farrell and co-supervisors Dr Graham Smith and Dr Andy Storey in the School of Politics and International Relations at University College Dublin for supporting and guiding me through the elaboration of my doctoral thesis. I would also like to thank both the Editor and the two anonymous reviewers who gave insightful and encouraging feedback on the article.

\section{Note}

1. Housing Council Resolution 06, 24 May 2011.

\section{References}

Abers R (2000) Inventing Local Democracy: Grassroots Politics in Brazil. Boulder, CO: Lynne Rienner Publishers.

Abers RN and Keck ME (2009) Mobilizing the State: The Erratic Partner in Brazil's Participatory Water Policy. Politics Society 37: 289-314.

Abers R and Bülow MU (2011) Movimentos sociais na teoria e na prática [Social Movements in Theory and Practice]. Sociologias 13: 52-84.

Abers R, Serafim L and Tatagiba L (2014) Repertórios de interação estado-sociedade em um estado heterogêneo: a experiência na Era Lula [Repertory of State-Society Interaction in a Heterogeneous State: The Experience in the Lula Era]. Dados 57: 325-357.

Albuquerque MDC (2019) Analisando impactos do movimento social na construção da política socioeducativa: coalizões de defesa e encaixes [Analyzing Impacts of the Social Movement in the Construction of Socio-Educational Policy: Defense Coalitions and Fittings]. In: Movimentos Sociais, Institucionalização e Domínios de Agência. Rio de Janeiro, Brazil: Editora UERJ, pp. 211252.

Avritzer A (2009) Participatory Institutions in Democratic Brazil. Baltimore, MD: Johns Hopkins University Press.

Avritzer L (2010) Living under a Democracy: Participation and Its Impact on the Living Conditions of the Poor. Latin American Research Review 45 (4): 166-185.

Baiocchi G (2001) Participation, Activism, and Politics: The Porto Alegre Experiment and Deliberative Democratic Theory. Politics \& Society 29: 43-72.

Bohn SR (2011) Social Policy and Vote in Brazil: Bolsa Família and the Shifts in Lula's Electoral Base. Latin American Research Review 46: 54-79.

Boyatzis RE (1998) Transforming Qualitative Information: Thematic Analysis and Code Development. Thousand Oaks, CA: SAGE Publishing.

Bronstein MM, Filho F, Rubens J, et al. (2017) Organização dos Conselhos Municipais: governança e participação da sociedade civil [Municipal Councils Organization: Governance and Civil Society Participation]. Interações (Campo Grande) 18: 89-102.

Buonfiglio LV (2017) Novos elementos teóricos sobre o Estado Brasileiro na última década: Análise do governo Lula-Dilma [New Theoretical Elements about the Brazilian State in the Last Decade: LulaDilma Government Analysis]. Espaço e Economia. Revista brasileira de geografia econômica 11: $1-17$.

Canel E (1997) New Social Movement Theory and Resource Mobilization Theory: The Need for Integration. In: Kaufman M and Alfonso H (eds) Community Power and Grassroots Democracy: The Transformation of Social Life. London: Zed Books, pp.189-221.

Carlos E (2015) Movimentos sociais e instituições participativas. Efeitos do engajamento institucional nos padrões de ação coletiva [Social Movements and Participatory Institutions. Effects of Institutional Engagement on Collective Action Patterns]. Revista Brasileira de Ciências Sociais 30 : 83-98. 
Coaffee J and Healey P (2003) 'My Voice: My Place': Tracking Transformations in Urban. Urban Studies 40: 1979-1999.

Coelho FA and Costa MCL (2017) As transformações urbanas, políticas públicas e a vulnerabilidade social no município de caucaia-ce (2000-2010). In: Regimes Urbanos e Governança Metropolitana. Presented at the Encontro Nacional da Rede de Observatório das metrópoles, Rio Grande do Norte, March 2017.

Coy PG and Hedeen T (2005) A Stage Model of Social Movement Co-Optation: Community Mediation in the United States. The Sociological Quarterly 46: 405-435.

Dagnino E and Tatagiba L (2010) Mouvement sociaux et participation institutionnelle: répertoires d'action collective et dynamiques culturelles dans la difficile construction de la démocratie brésilienne. Revue internationale de politique comparée 17: 167-186.

Dagnino E and Teixeira ACC (2014) The Participation of Civil Society in Lula's Government. Journal of Politics in Latin America 6: 39-66.

de Almeida LQ (2005) Socio-Environmental Diagnosis and Contributions for the Environmental Planning in the City of Maracanaú. Caminhos de Geografia 11: 108-125.

de Jong S and Kimm S (2017) The Co-Optation of Feminisms: A Research Agenda. International Feminist Journal of Politics 19: 185-200. de Oliveira Santos E (2013) Interfaces entre a política habitacional e o plano diretor participativo na metrópole. Sociedade \& Natureza 25: 485-501.

Dinerstein AC, Contartese D, Deledicque M, et al. (2013) Movimientos sociales y autonomía colectiva: la política de la esperanza en América Latina [The Politics of Autonomy in Latin America - The Art of Organising Hope], 1st edn, Claves del siglo XXI. Buenos Aires, Argentina: Capital Intelectual.

Druck G (2006) Os sindicatos, os Movimentos Sociais e o Governo Lula: Cooptação e Resistencia [Unions, Social Movements and the Lula Government: Cooptation and Resistance]. CLACSO, Consejo Latinoamericano de Ciencias Sociales Vl: 329-340.

Fominaya CF (2015) Debunking Spontaneity: Spain's 15-M/Indignados as Autonomous Movement. Social Movement Studies 14: 142-163.

Freitas CFS (2014) llegalidade e degradação em Fortaleza: os riscos do conflito entre a agenda urbana e ambiental brasileira [lllegality and Degradation in Fortaleza: The Risks of the Conflict between the Brazilian Urban and Environmental Agenda]. urbe. Revista Brasileira de Gestão Urbana 6: 109125.

Fung A and Wright EO (2003) Countervailing Power in Empowered Participatory Governance. In: Fung A and Wright EO (eds) Deepening Democracy: Institutional Innovations in Empowered Participatory Governance. London: Verso, pp.259-291.

Gamson WA (1990) The Strategy of Social Protest, subsequent edn. Belmont, CA: Wadsworth Pub Co. Garmany J (2011) Situating Fortaleza: Urban Space and Uneven Development in Northeastern Brazil. Cities 28: 45-52.

Garmany J (2014) Space for the State? Police, Violence, and Urban Poverty in Brazil. Annals of the Association of American Geographers 104: 1239-1255.

Giugni M and Passy F (1998) Contentious Politics in Complex Societies: New Social Movements between Conflict and Cooperation. In: McAdam D, Giugni M and Tilly C (eds) From Contention to Democracy. Lanham, MD: Rowman \& Littlefield, pp.81-107.

Gohn MG (2008) Novas teorias dos movimentos sociais [New Theories of Social Movements]. São Paulo, Brazil: Edições Loyola.

Hamel P (2014) Urban Social Movements. In: van der Heijden H-A (ed.) Handbook of Political Citizenship and Social Movements. Cheltenham: Edward Elgar Publishing, pp.464-492.

Holdo M (2016a) Reasons of Power: Explaining Non-co-optation in Participatory Budgeting. International Journal of Urban and Regional Research 40: 378-394.

Holdo M (2016b) Deliberative Capital: Recognition in Participatory Budgeting. Critical Policy Studies 10: 391-409.

Holdo M (2019) Co-Optation and Non-Co-Optation: Elite Strategies in Response to Social Protest. Social Movement Studies 18: 444-462. 
Jenkins JC and Klandermans B (1995) The Politics of Social Protest. London: UCL Press.

Katzenstein DS (1998) Stepsisters: Feminist Movement Activist in Different Institutional Spaces. In: Meyer DS and Tarrow SG (eds) The Social Movement Society: Contentious Politics for a New Century. Lanham, MD: Rowman \& Littlefield, pp.195-216.

Kriesi H, Koopmans R, Duyvendak JW, et al. (1995) New Social Movements in Western Europe: A Comparative Analysis, NED-New edition. ed. University of Minnesota Press.

Kriesi H (1996) The Organizational Structure of New Social Movements in Relation to Their Political Context. In: McAdam D, McCarthy JD and Zald MN (eds) Comparative Perspectives on Social Movements (Cambridge Studies in Comparative Politics). Cambridge: Cambridge University Press, pp.152-184.

Lavalle AG and Bueno NS (2011) Waves of Change within Civil Society in Latin America: Mexico City and São Paulo. Politics \& Society 39: 415-450.

Lavalle AG, Carlos E, Dowbor M, et al. (2019) Movimentos sociais, institucionalização e domínios de agência [Social Movements, Institutionalization and Agency Domains]. Rio de Janeiro, Brazil: Editora UERJ.

Lavalle AG, Voigt J and Serafim L (2016) O que Fazem os Conselhos e Quando o Fazem? Padrões Decisórios e o Debate dos Efeitos das Instituições Participativas [What Do Councils Do and When They Do It? Decision Patterns and the Debate of the Effects of Participatory Institutions]. Dados 59: 609-650.

Lima V (2011) Programa de Habitação de Interesse Social em Maracanaú/CE [Social Housing Program in Maracanaú/CE]. Master's Thesis, State University of Ceara, Ceará, Brazil.

Lima V (2018) Social Housing under the Workers' Party Government: An Analysis of the Private Sector in Brazil. Third World Quarterly 39: 1640-1655.

Lima V (2019) The Limits of Participatory Democracy and the Inclusion of Social Movements in Local Government. Social Movement Studies 18: 667-681.

Maricato E (2014) Impasse da Política Urbana No Brasil [Urban Policy Stalemate in Brazil]. Sao Paulo, Brazil: Editora Vozes.

Meyer DS and Tarrow SG (1998) The Social Movement Society: Contentious Politics for a New Century. Lanham, MD: Rowman \& Littlefield.

Munck R (2013) Rethinking Latin America. New York: Palgrave Macmillan.

Murphree DW, Wright SA and Ebaugh HR (1996) Toxic Waste Siting and Community Resistance: How Cooptation of Local Citizen Opposition Failed. Sociological Perspectives 39: 447-463.

Nogueira AS (2018) Institucionalização dos movimentos sociais agrários urante o governo de Lula e o declínio da reforma agrária no Brasil: cooptação, identidade política e agência [Institutionalization of Agrarian Social Movements during Lula's Government and the Decline of Agrarian Reform in Brazil: Co-Optation, Political Identity and Agency]. Análise Socia/227: 362387.

Nylen WR (2011) Participatory Institutions in Latin America: The Next Generation of Scholarship. Comparative Politics 43: 479-497.

O'Hare P (2018) Resisting the 'Long-Arm' of the State? Spheres of Capture and Opportunities for Autonomy in Community Governance. International Journal of Urban and Regional Research 42: 210-225.

Oliveira G and Dowbor M (2018) As relações entre movimentos sociais e Estado pelo prisma da autonomia [The Relationship between Social Movements and the State through the Prism of Autonomy]. In: Proceedings of the 42th ANPOCS, Caxambu, Brazil, 22-26 October.

Rich J (2019) State-Sponsored Activism: Bureaucrats and Social Movements in Democratic Brazil. Cambridge: Cambridge University Press.

Rodrigues AM (2012) A Política Urbana no Governo Lula (2003-2010) [The Urban Policy in Lula's Government (2003-2010)]. Revista Continentes 1: 38-55.

Rolnik R (2019) Urban Warfare - Housing Under the Empire of Finance. London: Verso. 
Rossi FM (2017) The Poor's Struggle for Political Incorporation: The Piquetero Movement in Argentina. Cambridge: Cambridge University Press.

Rucht D (ed.) (1995) Left-Libertarian Movements in Context: A Comparison of Italy and West Germany, 1965- 1990. In: Craig Jenkins J and Klandermans B (eds) The Politics of Social Protest: Comparative Perspectives on States and Social Movements. Minneapolis, MN: University of Minnesota Press, pp.229-272.

Saldaña J (2009) The Coding Manual for Qualitative Researchers, 1st edn. Los Angeles, CA: SAGE Publishing. Scheper-Hughes N (1992) Death without Weeping. Berkeley, CA: University of California Press.

Schwartz MA (2010) Interactions between Social Movements and US Political Parties. Party Politics 16: 587-607.

Selee A and Peruzzotti E (Eds) (2009) Participatory Innovation and Representative Democracy in Latin America, 1st edn. Baltimore, MD: Johns Hopkins University Press.

Selznick P (1949) TVA and the Grass Roots: A Study of Politics and Organization. Berkeley, CA: University of California Press.

Tarrow S (2012) Strangers at the Gates: Movements and States in Contentious Politics, 1st edn. Cambridge and New York: Cambridge University Press.

Tarrow S and McAdam D (2001) Dynamics of Contention. Cambridge and New York: Cambridge University Press.

Tatagiba L (2011) A questão dos atores, seus repertórios de ação e implicações para o processo participativo [The Question of Actors, Their Repertoire of Action and Implications for the Participatory Process]. In: Diálogos Para o Desenvolvimento - Efetividade Das Instituições Participativas No Brasil: Estratégias de Avaliação, vol. 7. Rio de Janeiro, Brazil: IPEA, pp. 171-186.

Trumpy AJ (2008) Subject to Negotiation: The Mechanisms behind Co-Optation and Corporate Reform. Social Problems 55: 480-500.

Van Dyck B and Montero AP (2015) Eroding the Clientelist Monopoly: The Subnational Left Turn and Conservative Rule in Northeastern Brazil. Latin American Research Review 50: 116-138.

Wampler B (2007) Participatory Budgeting in Brazil: Contestation, Cooperation, and Accountability. University Park, PA: Penn State University Press.

Wolff J (2007) (De-)Mobilising the Marginalised: A Comparison of the Argentine Piqueteros and Ecuador's Indigenous Movement. Journal of Latin American Studies 39: 1-29.

\section{Author Biography}

Valesca Lima is a Postdoctoral Researcher at Maynooth University, Ireland. She is the author of Participatory Citizenship and Crisis in Contemporary Brazil(Palgrave MacMillan, 2020) and has written extensively on social movements, governance and housing justice. 